\title{
Editorial: Pension crisis in China
}

After the founding of the People's Republic of China in 1949, most urban workers were employed by State-owned enterprises. Their employment terms gave almost total security but low wages plus comprehensive benefits. In particular, on retirement at age 60 (males), 50 or 55 (females) a very generous pension of about 80 per cent of final salary became payable. Pensions were paid from cash flow, ie, there was no pre-funding.

In the 1980s this system came under increasing strain because of:

- demographics

- economic reform.

In the 1990s many provinces and cities experimented with various arrangements which required employees and employers to contribute to pension funds or welfare funds. At the same time China's one-child policy together with much improved life expectancy clearly began to affect the old system. The forecasts are for the demographics to worsen significantly.

The World Bank has produced reports on China recommending the adoption of a 'Three-Pillar Approach'. The Three Pillars reflect the reality that financial security in old age has to come from some or all of three sources:

- the State

- the employer

— the individual.
In July 1997 the State Council issued Document 26 on the New Unified Pension System. This System was to be implemented not later than 1st January, 1999, applied to all workers in the urban sector and is to operate on a provincial basis. The New System comprises:

- basic pension of 20 per cent of average provincial wages

- pension from individual account of 11 per cent accumulated contributions

- voluntary supplementary pension.

The required contributions are 4 per cent from employees, rising to 8 per cent by 2007 , and approximately 20 per cent from the employer.

The implicit forces behind Document 26 are:

- to reduce pension entitlements

- to require employers and employees to provide for their own pensions

- to introduce a funded system and help develop China's capital markets.

The System is now in effect but is not working properly in many provinces.

The problems include:

- shortage of cash to pay benefits

— inability (or unwillingness) to make contributions

— inaccurate records

— inadequate funding

- lack of proper supervision

— no developed regulatory framework 
— likelihood of fraud/misapplication of funds

- certain industries' reluctance to participate in the System.

The nightmare scenario which could well result is:

- total distrust in the System

- serious civil unrest

- reversal of economic reforms.

The requirement is simply to move from the vicious circle outlined above to a vicious circle where:

- there is trust in the System

- contributions are collected timelessly

- benefits are paid in full and on time

- assets are invested prudently

- record keeping is 100 per cent accurate

- there is proper supervision and accountability.

From the financial point of view, it is essential to establish the real liabilities of the New System by actuarial valuation. This will then form the target for the macro-economic management of the System, whether by selling State-owned assets, issue of recognition bonds, special taxation or other measures.

In the meantime, there are certain vital and urgent steps to be taken:

- the leadership to place paramount importance on the success of the New System

- pay all arrears of outstanding pensions immediately (say 50 per cent by central Government, 50 per cent by provinces)

- enforce participation in New System and timely payment of contributions

- establish a Pensions Supervisory Body on a par with PBOC (banking), CSRC (securities) and CIRC (insurance) and independent of the Ministry of Finance and Ministry of Labour and Social Security

- monitor closely the build-up of assets in each province and require transparency on this

- consider an element of pooling on a national basis, to help the poorer provinces

- for supplementary pensions (Pillar 3) encourage both domestic and foreign companies to enter this market

- give the pensions dimension careful consideration when reviewing policy on other major issues, eg, healthcare, one-child policy, urbanisation.

Stuart H. Leckie, Actuary Hong Kong Editorial Board 